\title{
Boundaries and mosaics: an approach to evaluate changes and to profit landscape planning, São Sebastião Island, SP/Brazil
}

\author{
Fronteras y mosaicos: una aproximación para evaluar cambios y apoyar la planificación del paisaje, \\ São Sebastião Island- SP/Brazil
}

\author{
Lídia S Bertolo ${ }^{\text {a*, }}$ Pilar M de Agar ${ }^{\text {b, }}$ Carlos L de Pablo ${ }^{\text {b }}$, Rozely F Santos a,c \\ *Corresponding author: ${ }^{a}$ Campinas State University, Environmental Planning Laboratory, SP, Brazil, \\ tel.: (+55) (19)3521-2385, lidia_bertolo@yahoo.com.br \\ ${ }^{\mathrm{b}}$ Universidad Complutense de Madrid, Departamento de Ecología, Spain. \\ ' São Paulo University, Department of Ecology, Brazil.
}

\begin{abstract}
SUMMARY
This study assumed that the spatial identification of mosaics obtained by the analysis of interactions between frontiers over time would be a great strategy to obtain planning units, since the boundaries reveal the changes, heterogeneity and fluxes in a landscape. For this purpose, we selected 16 watersheds in São Sebastião Island (São Paulo, BR), mapped the land use and cover (1962 and 2009 ) and built matrices of patches by boundaries. The analysis of these matrices using multivariate ordination and clustering allowed us to identify mosaics. The mosaics showed very well the temporal diversity of interactions across frontiers and the landscape conservation status, but had limitations to indicate management practices.
\end{abstract}

Key words: environmental planning, forest conservation, landscape ecology.

\section{RESUMEN}

Este estudio asume que la identificación espacial de mosaicos obtenida a través del análisis de interacciones entre fronteras en el tiempo sería una buena estrategia para obtener unidades de planificación, ya que los límites revelan los cambios, heterogeneidad y flujos en un paisaje. Para este propósito, se seleccionaron 16 cuencas en São Sebastião Island (São Paulo, BR), se mapeó el uso y cobertura de suelo (1962 y 2009) y construyeron matrices de parches por fronteras. El análisis de estas matrices usando ordenación y agrupamiento multivariado permitió identificar los mosaicos. Los mosaicos mostraron bien la diversidad temporal de interacciones a través de las fronteras y el estado de conservación del paisaje, pero tuvieron limitaciones en indicar prácticas de manejo.

Palabras clave: planificación ambiental, conservación de bosque, ecología de paisaje.

\section{INTRODUCTION}

The Brazilian landscapes have been showing the multiplicity of accumulated uses over time, often resulting in very heterogeneous landscapes and generating major conflicts among social actors (Brito 2003). This territories are relevant to environmental planning (Polette and Silva 2003) because they are complex landscapes extremely fragile, which should be strongly conserved, but have numerous interests of human uses (Santos and Caldeyro 2007).

The heterogeneity, rarely discrete in a territory and derived from a wide range of habitats (Lovett et al. 2005); can be analyzed through the diversity of types and configuration of elements that compose the landscape, the intensity of interaction between these elements and the nature of the relationship between the elements (Mimra 1993). It can also be observed by different kinds of pressure over natural fragments (Gergel and Turner 2002), the porosity of the matrix (Coulson et al. 1999) or by connectivity between elements (Li and Reynolds 1995, McGarigal and Marks 1995). It is important to note that one can not directly relate landscape complexity to presence of impacts. De Pablo (2000) has shown that certain landscapes structures may or may not cause negative impacts, depending on the types and quantities of interactions among their elements.

Several authors have interpreted the heterogeneity using the patch-corridor-matrix model (Forman 1995, Dramstad et al. 1996). Another way is to evaluate mosaics that reproduce specific sets of elements and their interactions (Forman 1995, Roldán-Martin et al. 2003). This method identifies the mosaics as a set of patches with the same frequency of boundaries, that is, the same pattern of ecological interactions. Thus, they are part of a network of similar interactions (Cadenasso et al. 2003, Valverde et al. 2008). This conception assumes that boundaries or transition zones between patches are the areas where ecological flows take place, which can be altered by changes 
in the patterns of spatial arrangement (Roldán-Martin et al. 2006, Turner and Cardille 2007).

If each mosaic represents one aspect of heterogeneity and conservation status, it can be assumed that also it could have specific management actions. This is the premise evaluated in this study. This study aims to evaluate the possibility of identifying management units through mosaics defined by the interactions between frontiers.

\section{METHODS}

This study selected 16 watersheds of São Sebastião Island (municipality of Ilhabela, São Paulo, BR) facing the São Sebastião Channel (figure 1), since this area is the one that has suffered the most human influence over the last 500 years over the atlantic forest. Nevertheless, human actions on this island are heavily concentrated in its shoreline, retaining about $92 \%$ of forest conserved, being the Brazilian city with the greatest area/Atlantic Forest of the country (Bertolo et al. 2012).

The land use and land cover maps of the watersheds from 1962 and 2009 were made in ArcGIS9.2 from aerial photographs, scale 1:35.000 and SPOT 5 satellite images with a resolution of 10 meters. Based on those maps, matrices of patches by boundaries were prepared (figure 2A). The matrices were subjected to DECORANA ordination (DCA, figure 2B). The three axes of DCA were subjected to a hierarchical cluster analysis (euclidean distance) (figure 2C). The groups composed of this step represent the mosaics, showing similar patterns of frontiers based on their frequencies (Roldán-Martín et al. 2006, Valverde et al. 2008, Hardt 2010). The mosaics are specific clusters for each date, which has particular associations among their elements.

In order to compare changes between landscape mosaics over 47 years it is necessary to form mosaics with similar patterns. Thus, the mosaics of each year were regrouped and organized into a single matrix of mosaics by boundaries (figure 2D), subject to further analysis of ordination and variance. The mosaics have been characterized by ANOVA, with a cut off level of dendrogram determined on the 2-2 comparison of the frontiers frequencies observed in each bifurcation branch (figure $2 \mathrm{E}$ ).

\section{RESULTS}

We identified five mosaics in 1962 and 2009. Figure 3 shows the results of DCA of the mosaics identified in both years and the clustering made from their coordinates in the ordination axis. This information, together with the ANOVA and t-test, allowed the verification of just how different are the groups between themselves, and which boundaries contributed to the identification of the groups. Figure 4

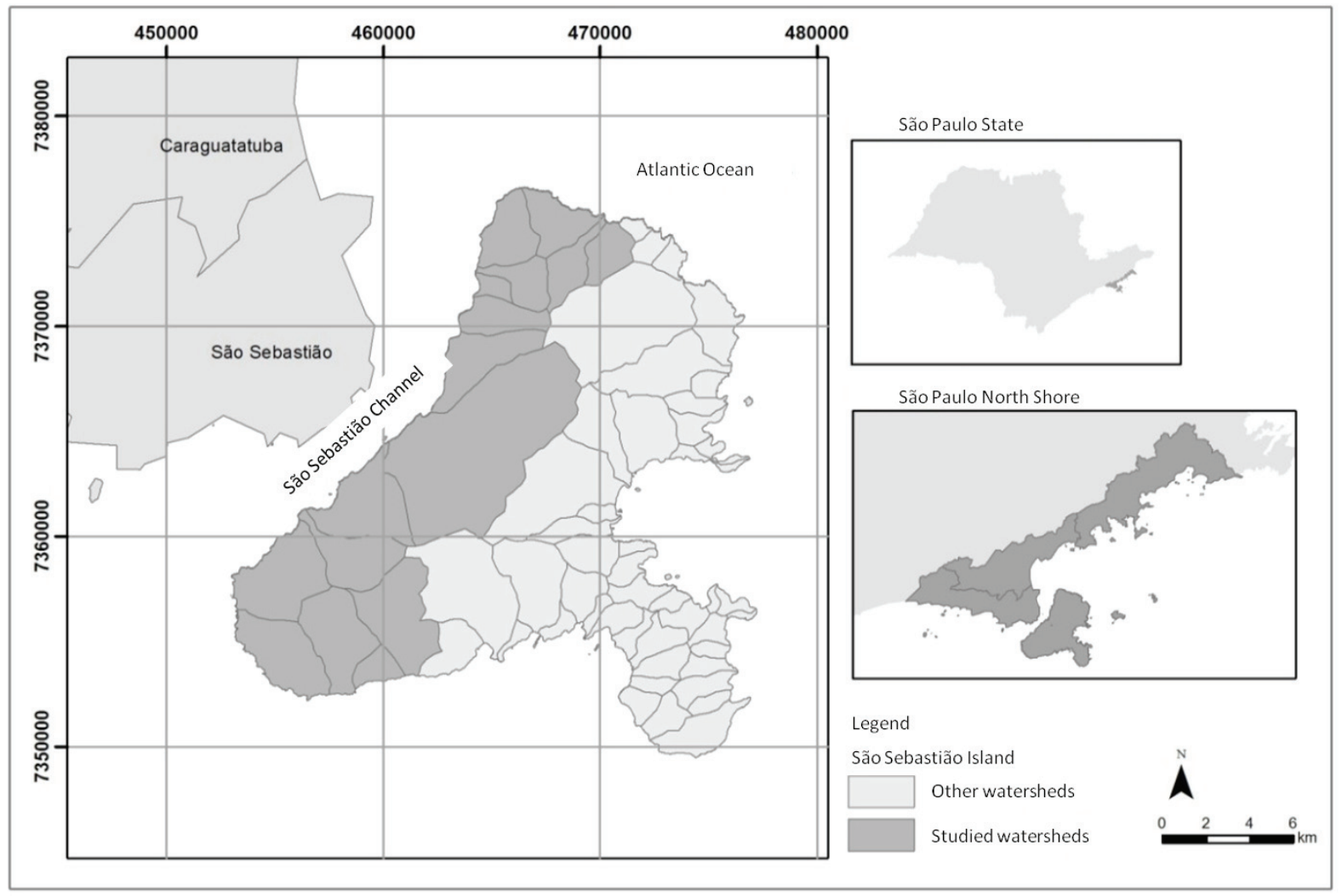

Figure 1. Location of São Sebastião Island. Ubicación de la Isla São Sebastião. 


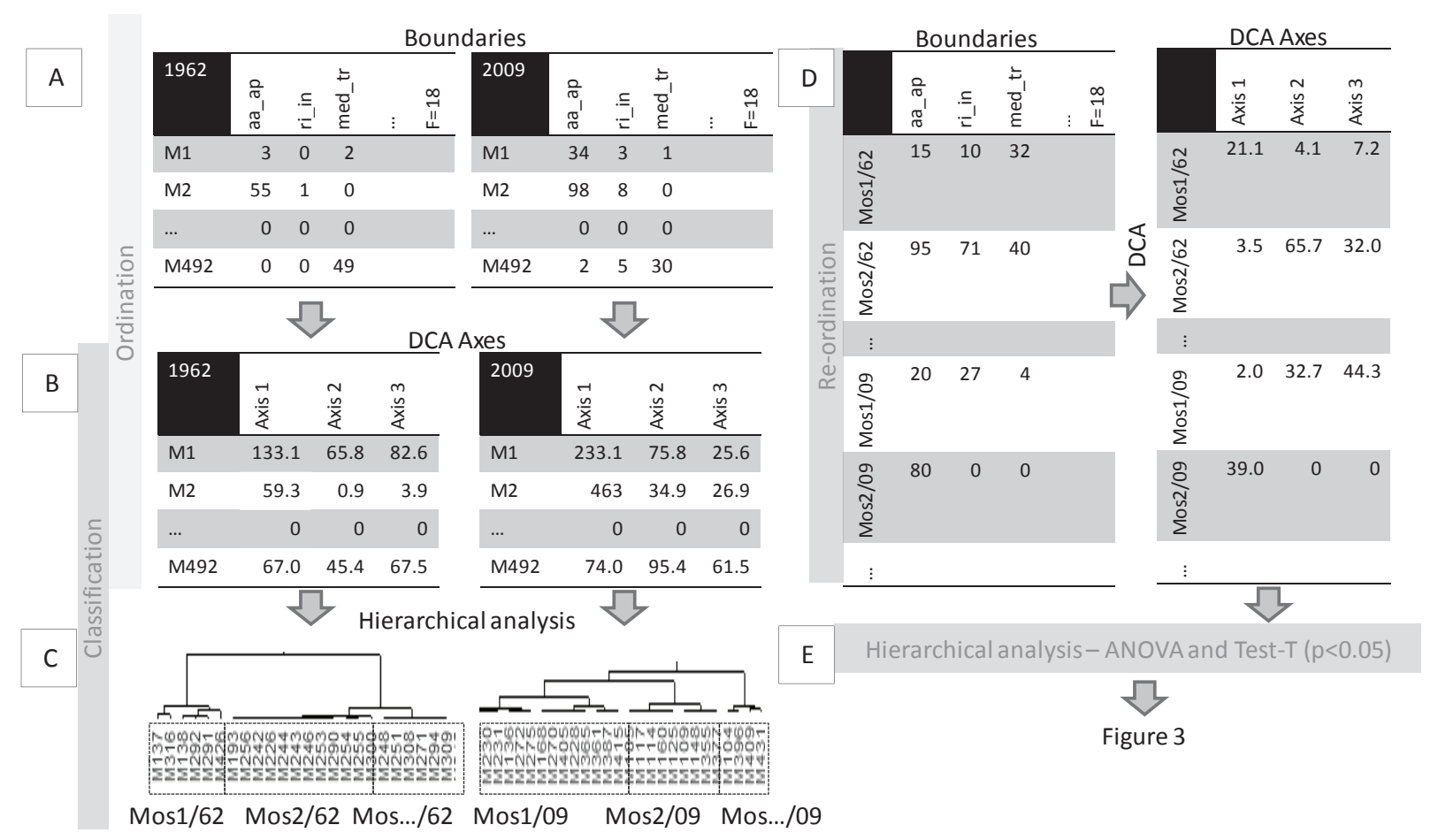

Figure 2. Methodological schema (adapted from Hardt 2010). Esquema metodológico (adaptado de Hardt 2010).

shows the spatial distribution of mosaics and their description in terms of area, boundaries and uses.

\section{DISCUSSION}

The results show that over 40 years of landscape study, there were no major changes in the dominant uses or even in relation to areas occupied by forest, inclusive pointing to an increase of forest amount (figure 4D). However, the mosaics denote that the network of interactions through boundaries has substantially changed (figure 4C). Mosaic five, for example, with the landscape higher conservation status, has an increase in patches number and frontiers (figure 4B), which may have affected the quality of forest, although it maintained the same land uses in 1962 and 2009. We also highlight mosaic 3 , which has always been occupied predominantly by forest in initial succession stage (figure 4D). Despite this condition, the mosaic presents a large number of land uses boundaries that has been expanded over time (figure 4BC).

We defend the idea that, despite the same conditions of land uses, different situations of boundaries can affect the forests and their territories in a quite distinct way. Some researchers show that structural arrangements of boundaries provide evidence of change in ecological condition, indicate ecological complexity and influence on flows between patches (Fortin et al. 1996, With 2005, Teixido et al. 2010). It suggests that mosaics based on boundaries can denote changes and conservation status that are not visible by land use areas. One can infer that some territories with high percentage of forests also need management, due the influence of boundary number and richness that have been established over time.

These findings strengthen the observations of other authors that indicate the mosaic as a functional space, which reflects the interaction between landscape elements and highlights the relationships between major patches, providing good support to understand the environmental supply and territory management decisions (Zeng and $\mathrm{Wu}$ 2005, Valverde et al. 2008). However, it is important to remember that mosaics are the manifestation of the ecological interactions at different levels of detail. There are certain scales that have reasonable descriptive capacity, but do not have an adequate performance from the management viewpoint. This study is an example, because the adopted scale does not consider all the uses relations that are important for the management. Depending on the scale, mosaics could be more useful for describing landscape or defining management guidelines.

\section{CONCLUSIONS}

The mosaics assess over time allow to show the temporal diversity of interactions across boundaries, indicating changes and conservation status that are not visible by land use areas. We infer that some mosaics with high percentage of forests also need management, despite of the conservation condition. However the mosaics are not effi- 

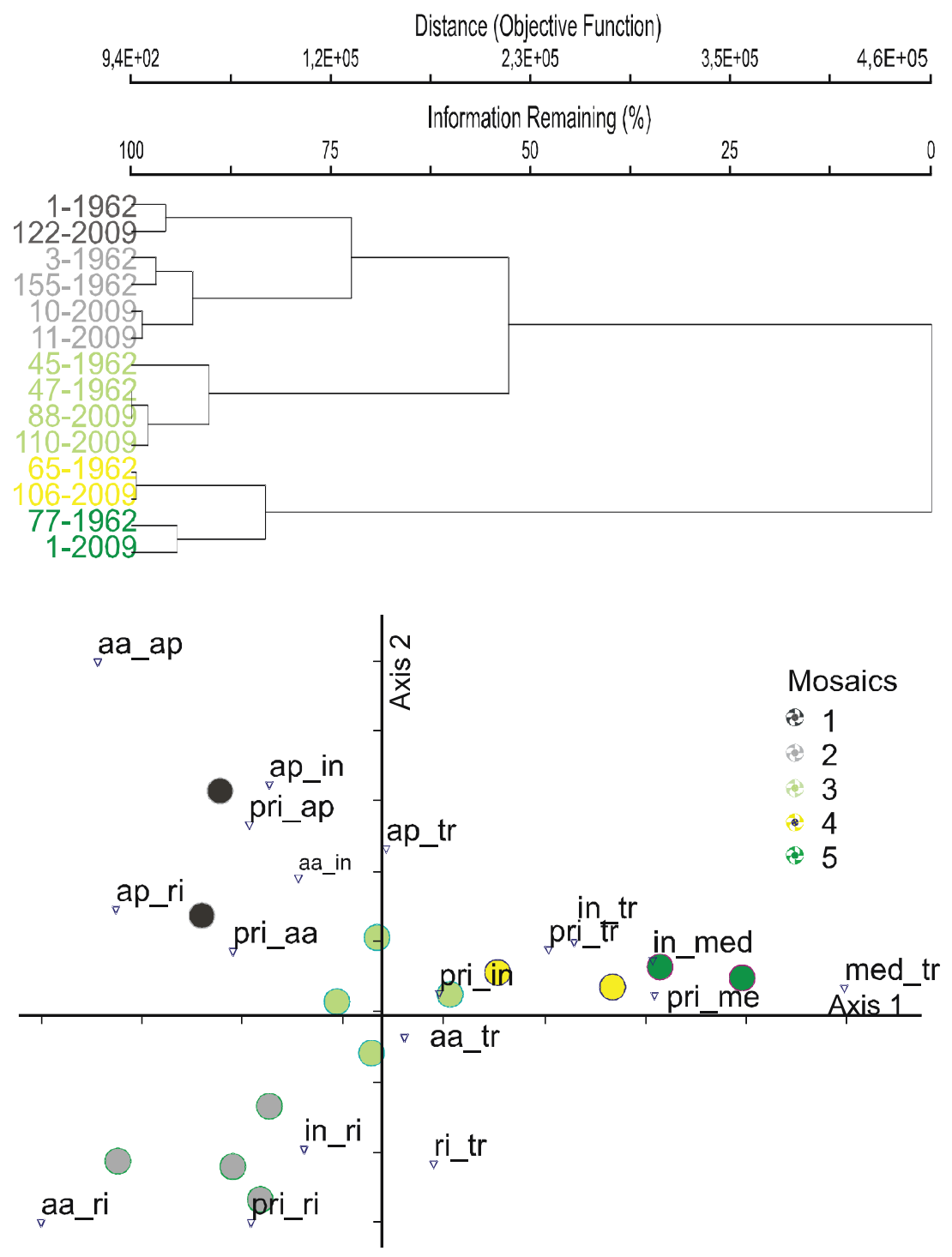

Figure 3. Mosaics obtained from DCA and cluster analysis (land uses: aa-stepping stones; ap-urban concentration; in-forest (initial stage); med-forest (intermediate/late stage); pri-forest (pioneer stage); ri-isolated residences; tr-trails).

Mosaicos obtenidos a partir del análisis DCA y de cluster. Usos de suelo: aa-escalones; ap-concentración urbana; in-bosque (en estado inicial); med-bosque (en estado medio/tardío); pri-bosque (en estado pionero); ri-residencias aisladas; tr-senderos.

cient as effective planning units in function of the adopted scale. Mosaics are more adequate to description than management. It is important to study how articulate both the description and management.

\section{ACKNOWLEDGMENTS}

This research was funded by CAPES and Fundação Carolina. We would also like to thank for the Foundation Forest, the administration of Ilhabela State Park.

\section{REFERENCES}

Bertolo L S, G Lima, R Santos. 2012. Identifying change trajectories and evolutive phases on coastal landscapes. Case study: São Sebastião Island, Brazil. Landscape and Urban Planning 106(1): 115-123.

Brito M. 2003. Unidades de Conservação: Intenções e Resultados. $2^{\text {nd }}$ ed. São Paulo, Brasil. Anna Blume: FAPESP. 230 p.

Cadenasso ML, S Pickett, K Weathers, C Jones. 2003. A framework for a theory of ecological boundaries. BioScience 53(8): 750-758.

Coulson RN, BA Fadden, PE Pulley, CN Lovelady, JW Fitzgerald, SB Jack. 1999. Heterogeneity of forest landscapes and the distribution and abundance of the southern pine beetle. Forest Ecology and Management 114 (2-3): 471-485.

De Pablo CL. 2000. Cartografía ecológica: conceptos y procedimientos para la representación espacial de ecosistemas. Boletín de la Real Sociedad Española de Historia Natural 96 (1-2): 57-68. 

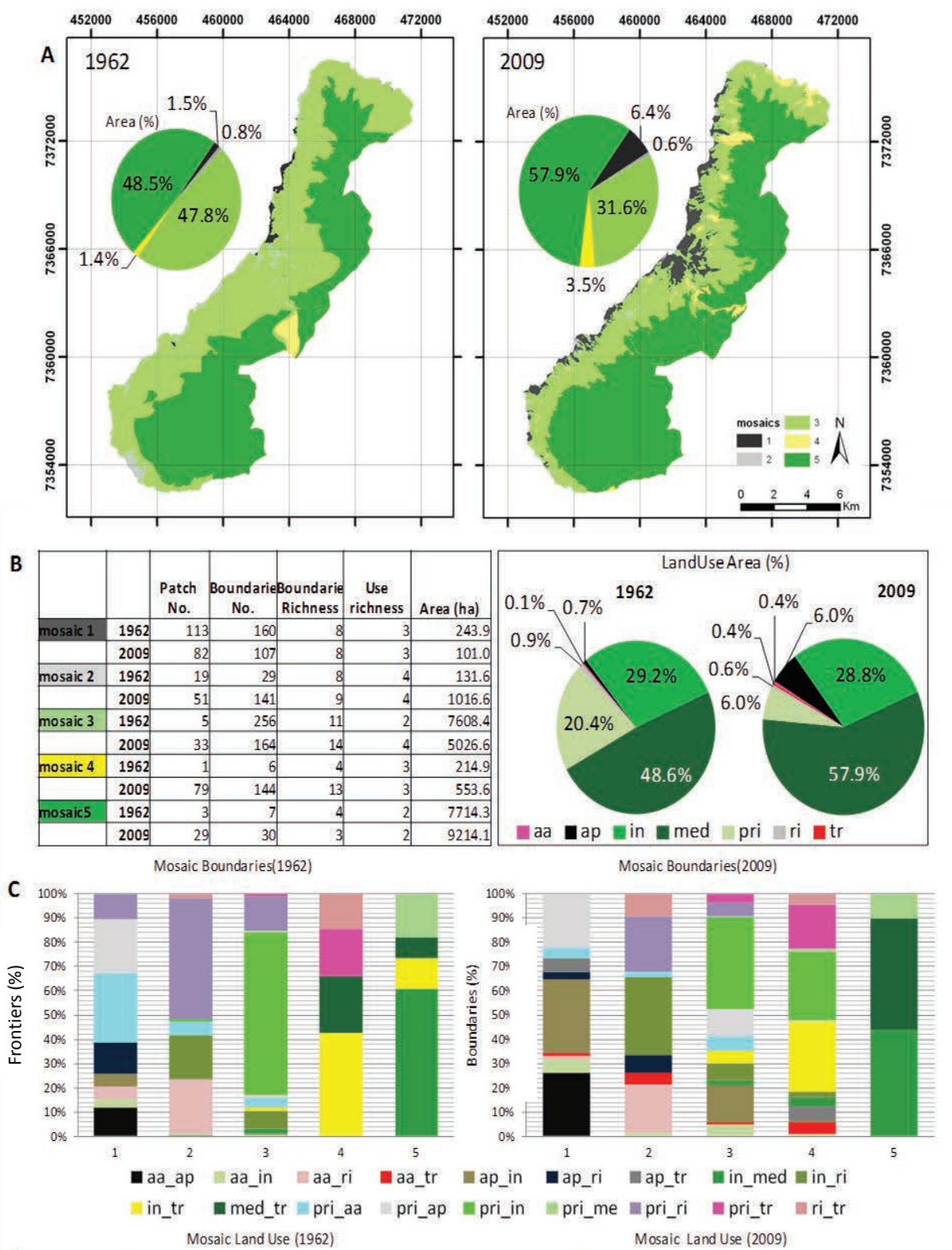

D
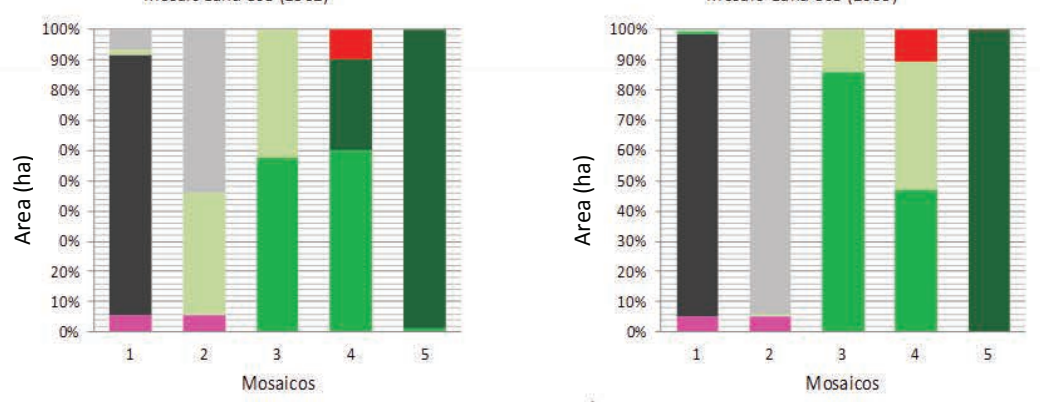

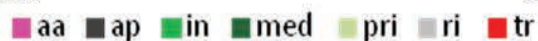

Figure 4. Mosaics, boundaries and land uses of 1962 and 2009 (A) types of mosaics; (B) characteristics and percentage of each mosaic; (C) relative frequency of boundaries; (D) land use relative area.

Mosaicos, fronteras y usos de suelo en 1962 y 2009 (A) tipos de mosaicos; (B) características y porcentaje de cada mosaico; (C) frecuencia relativa de fronteras; (D) área relativa de usos de suelo. 
Dramstad W, J Olson, R Forman. 1996. Landscape ecology principles in landscape architecture and land-use planning. Washington, USA. Island Press. $80 \mathrm{p}$.

Forman R. 1995. Land mosaics: the ecology of landscapes and regions. Cambridge, UK. Cambridge University Press. 605 p.

Fortin M, P Drapeau, G Jacquez. 1996. Quantification of the spatial co-occurrences of ecological boundaries. Oikos 77: 51-60.

Hardt E. 2010. Conservação ambiental em cenários de uso: medidas de mudanças, heterogeneidade e valoração da paisagem. Ph.D. Thesis. Campinas, SP, Brasil. Universidade Estadual de Campinas. $192 \mathrm{p}$.

Li H, J Reynolds. 1995. On definition and quantification of heterogeneity. Oikos 73: 280-284.

Lovett G, C Jones, M Turner, K Weathers. 2005. Ecosystem function in heterogeneous landscapes. New York, USA. Springer. $489 \mathrm{p}$.

Mcgarigal K, B Marks. 1995. FRAGSTATS: spatial pattern analysis program for quantifying landscape structure. USDA Forest Service General Technical Report PNWGTR-351. Portland, OR, USA. Pacific Northwest Research Station. 122 p.

Mimra M. 1993. Spacial Heterogeneity Assessment of Cultural Landscape. Ph.D. Thesis. Prague, Czech. Czech University of Agriculture. 202 p.

Polette M, L Silva. 2003. GESAMP, ICAM E PNGC - Análise comparativa entre as metodologias de gerenciamento costeiro integrado. Ciência e Cultura 55(4): 27-31.

Roldán-Martín M J, C de Pablo, P Agar. 2003. Landscape mo- saics recognition and changes over time: a methodological approach. In Mander U, M Antrop eds. Multifunctional landscapes: continuity and change, v.3 Continuity and change. Southampton. $264 \mathrm{p}$.

Roldán-Martín M, C de Pablo, P Agar. 2006. Landscape changes over time: comparison of land uses, boundaries and mosaics. Landscape Ecology 21: 1075-1088.

Santos RF, V Caldeyro. 2007. Paisagens, condicionantes e mudanças. In Santos RF ed. Vulnerabilidade ambiental. Brasília, DF, Brasil. Ministério do Meio Ambiente.13-22 p.

Teixido AL, L Quintanilli, F Carreno, D Gutierrez. 2010. Impacts of changes in land use and fragmentation patterns on Atlantic coastal forests in northern Spain. Journal of Environmental Management 91: 879-886.

Turner MG, J Cardille. 2007. Spatial heterogeneity and ecosystem processes. In Wu J, RJ Hobbs eds. Key topics in landscape ecology. Cambridge, UK. Cambridge University Press. p. 62-77.

Valverde V, M Roldán-Martín, G Campos, P Pérez, P Agar, C de Pablo. 2008. Análisis de la estructura espacial del paisaje: mosaicos del paisaje. In Maestre FT, A Escudero, A Bonet eds. Introducción al análisis espacial de dados en ecología y ciencias ambientales: métodos y aplicaciones. p. 747-759.

With KA. 2005. Landscape conservation: a new paradigm for the conservation of biodiversity. In Wiens J, M Moss. Issues and perspectives in landscape ecology. Cambridge, UK. Cambridge University Press. p. 238-247.

Zeng H, BX Wu. 2005. Utilities of edge-based metrics for studying landscape fragmentation. Computers, Environment and Urban Systems 29: 159-178. 